\title{
Growth Inhibitors of Rust Fungi Detected in Healthy Oat Leaves*
}

\author{
Kensuke NABETA**, Genichi KADOTA**, Toshikazu TANI** \\ and Hiroshi SHIGA** \\ 鍋田憲助**・門田源一**・谷 利一**・志賀宏志**：健全エンバク葉に \\ 存在するさび菌発育阻害物質
}

\begin{abstract}
Two antifungal steroids were isolated from the water homogenate of oat primary leaves and were identified as 26-desglucoavenacosides (26-DGA) A and B, respectively. O"-Rhamnosylisoswertisin (RIS) and unidentified flavonoid (UF) were also isolated as inhibitors. Inhibition tests to germ tube growth of Puccinia coronata avenae showed that 26-DGA A and B were potent inhibitors $\left(\mathrm{ED}_{80}=14 \mu \mathrm{g} / \mathrm{ml}\right)$, compared with RIS and $\mathrm{UF}\left(\mathrm{ED}_{50}=1,500\right.$ and $500 \mu \mathrm{g} / \mathrm{ml}$, respectively). The contents of 26-DGA $\mathrm{A}$ and $\mathrm{B}$ in the water homogenate from $1 \mathrm{~g}$ fresh leaves were 280 and $930 \mu \mathrm{g}$, respectively, while only trace amounts of 26-DGAs were detected in the hot methanol extract of intact leaves. In contrast, the contents of RIS and UF were 750 and $300 \mu \mathrm{g} / \mathrm{ml}$, respectively, in both the water homogenate and hot methanol extract. No inhibitor other these four substances could be obtained. It was indicated that antifungal activity of the water homogenate is mainly attributable to 26-DGAs, whereas that in intact leaves is due to RIS and UF. No participation of these four inhitors as preformed substances was suggested in the species-species specificity in oat-rust combinations.

(Received October 7, 1977)
\end{abstract}

\section{Introduction}

The wide distribution of antifungal substances has been demonstrated for various plant tissues ${ }^{13)}$. Some of these substances are implicated to be responsible for the disease resistance of plants",9), and called as "preformed (antifungal) substance"or" prohibitin and inhibitin" 2,6 . As a part of the study on the antifungal resistance of oat leaves against rust fungi, we examined to isolate any antifungal substance present in healthy oat leaves and found that the water homogenate of primary leaves contained four antifungal substances; two of which were characteristic of steroidal glycosides and the others were of flavonoids. The former two were extremely strong inhibitors of uredospore germination. Chemical and physical analysis revealed that these steroids were identical to 26-desglucoavenacosides (26-DGA) A and $\mathrm{B}$ which had been reported by Tschesche and Wiemann ${ }^{12)}$.

This paper describes (a) constituents of antifungal substances in oat leaves and (b) structure elucidation of the two antifungal steroids, and (c) evaluates the antifungal activity of these in comparison with that of the two antifungal flavonoids

* Supported in part by Grant from the Ministry of Education, Science and Culture of Japan (No. 156034).

** Faculty of Agiculture, Kagawa University, Kagawa 761-07, Japan 香川大学農学部 
found in oat leaves. Chemical structure of one flavonoid has been determined as O"-rhamnosylisoswertisin (RIS), a new compound from plants ${ }^{7)}$, and that of the other (UF) is not yet identified.

\section{Materials and Methods}

Fractionation of leaf constituents. Seeds of oat (Avena sativa L.; cultivar Shokan 1) were grown on Vermiculite as described earlier ${ }^{10)}$. Primary leaves of 7-day-old seedlings ( $1 \mathrm{~g}$ fr. wt) were homogenated in deionized water and filtered through double layers of guaze. The filtrate was centrifuged at $1,000 \times g$ for 10 min. The solids obtained by filtration and centrifugation were washed in methanol $(\mathrm{MeOH})$ until free from chlorophyll and the washings were combined with the supernatant and dried in vacuo. To the dried material $40 \mathrm{ml}$ of $\mathrm{MeOH}$ was added and the soluble fraction was taken by centrifugation at $1,000 \times g$ for $10 \mathrm{~min}$ and dried in vacuo (Fr. M). The $\mathrm{MeOH}$ insoluble fraction was taken as Fr. W. Fr. $\mathrm{M}$ was washed with diethyl ether $\left(\mathrm{Et}_{2} \mathrm{O}\right)$ repeatedly until free from chlorophyll and the washings were collected as Fr. E. Insoluble fraction was dissolved in $10 \mathrm{ml}$ of $\mathrm{MeOH}$, added to 8 volumes of $\mathrm{Et}_{2} \mathrm{O}$ and kept in ice chilled condition for $2 \mathrm{hr}$. The precipitate formed was collected by centrifugation at $1,000 \times g$ for $10 \mathrm{~min}(\mathrm{Fr}$. A). The supernatant was combined with Fr. E. Fr. A was washed with $\mathrm{Et}_{2} \mathrm{O}$ repeatedly and dried in vacuo, dissolved in $4 \mathrm{ml}$ of $\mathrm{MeOH}$, then chromatographed over Sephadex $\mathrm{LH} 20$ column $(3 \times 30 \mathrm{~cm})$ with $\mathrm{MeOH}$. The fluorescent portion (under UV light) of the eluate was taken as steroid-rich fraction (Fr. S) and the yellowcolored portion was as flavonoid-rich fraction (Fr. F). For the extraction of each fraction from intact leaves, $1 \mathrm{~g}$ fresh leaves was first dipped into hot $\mathrm{MeOH}$ immediately after the harvest, homogenized and followed by the procedure as above.

Frs. S and $\mathrm{F}$ were further fractionated by thin-layer chromatography (TLC). Each sample was streched on a plate $(20 \times 20 \mathrm{~cm})$ coated with $0.25-\mathrm{mm}$-thick silica gel (Merck $\mathrm{GF}_{254} 60$ ) and developed with $\mathrm{CHCl}_{3}-\mathrm{MeOH}-\mathrm{H}_{2} \mathrm{O}(65: 35: 10 \mathrm{v} / \mathrm{v})$. Each of fluorescent and yellow-colored bands and other portions of the plate were scraped and eluted with $\mathrm{MeOH}$.

Purification and structure elucidation of antifungal substances. Fr. A from $30 \mathrm{~g}$ leaves was dissolved in $15 \mathrm{ml}$ of $\mathrm{CHCl}_{3}-\mathrm{MeOH}-\mathrm{H}_{2} \mathrm{O}(65: 35: 10 \mathrm{v} / \mathrm{v})$. Insoluble oily materials in the solution was removed by filtration through silica gel layer (Merck $60 ; 3 \times 3 \mathrm{~cm}$ ). The filtrate was concentrated in vacuo to dryness. The resulting solid was dissolved in $5 \mathrm{ml}$ of the same solvent system and chromatographed over silica gel column (Merck $60 ; 3 \times 45 \mathrm{~cm}$ ) to obtain the steroid and flavonoid fractions. The former fraction was rechromatographed over silica gel column $(1 \times 8 \mathrm{~cm})$ using the same solvent system, and two antifungal steroids, S-I and S-II, were obtained. The latter fraction was developed on the TLC as described above, and two antifungal flavonoids, RIS and UF, were obtained. The steroids were crystallized from dioxane- $\mathrm{MeOH}-\mathrm{H}_{2} \mathrm{O}$ and the flavonoids were from $\mathrm{CHCl}_{3}-\mathrm{MeOH}$. The yields of the crystals of S-I, S-II, RIS and UF from $1 \mathrm{~kg}$ leaves were 82, 24, 27 and $15 \mathrm{mg}$, respectively.

Infrared (IR) spectra were measured with a Hitachi 215 IR spectrophotometer and mass (MS) spectra were with JEOL-07 and JMS-01SG MS spectrophotometers. $[\alpha]_{\mathrm{D}}$ was determined by a Hitachi polarimeter PO-B.

Ouantitative assay of steroids and flavonoids. Frs. S and F from 20 leaves $(0.6 \mathrm{~g}$ fr. wt) which were prepared using the $1 \times 25 \mathrm{~cm}$ column of Sephadex LH 20 were dried in vacuo, dissolved in $5 \mathrm{ml}$ of $\mathrm{MeOH}$, and $100 \mu \mathrm{l}$ aliquots of each solution 
was spotted and developed by the TLC as described above. The plates were scanned with a Hitachi fluorescence spectrophotometer MPF-4. For estimation of steroid contents in spots, the plates were sprayed with $20 \% \mathrm{H}_{2} \mathrm{SO}_{4}$ to give about $0.1 \mathrm{mg} \mathrm{H}_{2} \mathrm{SO}_{4}$ per $\mathrm{cm}^{2}$, heated at $120 \mathrm{C}$, kept at room temperature for $1 \mathrm{hr}$ and the relative intensity of fluorescence was recorded under the condition of excitation at $420 \mathrm{~nm}$ and emission at $470 \mathrm{~nm}$. Each of the pure materials was used as a standard. For estimation of flavonoid contents the plates were scanned at $275 \mathrm{~nm}$ without any pre-treatment, and the amount in each spot was calculated from the intensity of absorbance of corresponding standard spots. The intensity of fluorescence of the two steroid spots was a function of the amount of samples charged in the ragne of 0.5 to $3.0 \mu \mathrm{g}$, and that of the two flavonoids was in the range of 10 to $50 \mu \mathrm{g}$.

Assay of antifungal activity. Puccinia coronata Cda. f. sp. avenae Fraser \& Led. races 226 and 203, P. coronata Cda. f. sp. lolii Eriks. \& Henn., P. coronata Cda. f. sp. festucae Eriks. \& Henn., P. graminis Pers. f. sp. tritici Eriks. \& Henn. and P. graminis Pers. f. sp. dactylidis Guyot. \& Massenot were used for germination tests. P. coronata avenae is a pathogen of oat and the others are non-pathogens. The test materials except 26-DGA A (S-II) were dissolved in deionized water. Since pure 26-DGA A was hardly soluble in water, this substance was dissolved in $0.05 \%$ solution of Fr. A which was extracted by hot $\mathrm{MeOH}$ from intact leaves and hence had no antifungal activity. Synchronousuredospores of these rust fungi were floated on a droplet of test solutions and kept in a moist chamber in darkness at $20 \mathrm{C}$ for $16 \mathrm{hr}$, then the length of germ tubes was measured.

\section{Results}

\section{Determination of chemical structures of antifungal steroids}

Structures of compounds and fragment ions of MS numbered by gothic letters in this section are illustrated by the same number in Figs. 1 and 4 , respectively.

Properties of S-I are as follows. Mp. 300-305 C, $[\alpha]_{\mathrm{D}}-60^{\circ}$ (pyridine, $\mathrm{C}=1.0$ ), analytical value (found: $\mathrm{C}, 54.60 ; \mathrm{H}, 7.80 . \mathrm{C}_{51} \mathrm{H}_{80} \mathrm{O}_{23} \cdot 3 \mathrm{H}_{2} \mathrm{O}$ requires; $\mathrm{C}, 54.92 ; \mathrm{H}$, 7.72\%). IR ( $\mathrm{KBr}$ ) spectrum of $\mathrm{S}-\mathrm{I}$ is shown in Fig. 2-A. The acetate of S-I, mp. 139-148 C, IR $\gamma_{\max }^{\mathrm{KBr}} \mathrm{cm}^{-}: 2950$ (s), 1750 (s), 1440 (s), 1370 (s), 1040 (s), 900 (s), showed the prominent MS ion peaks at $\mathrm{m} / \mathrm{e} 619(6,4 \%), 331(7,10 \%), 273(8,19 \%)$, indicating Glu-O-Glu-O- and Rham-O- moiety in the sugar part.

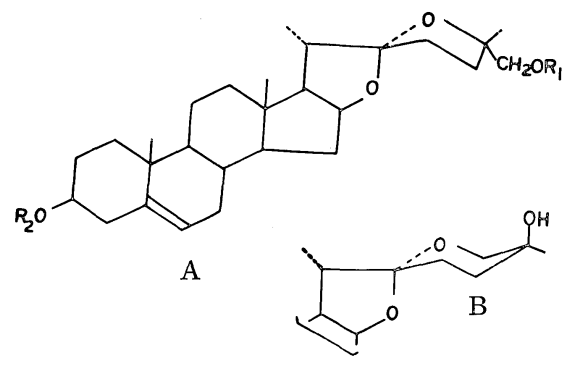

Fig. 1. Structures of 26-desglucoavenacosides (26-D $\mathrm{GA}$ ) and related compounds.
A : 1. 26-DGA B
2. 26-DGA A
$\mathrm{H}$ Rham-O-Ǵlu-O-Ǵlu-O-Glu
3. Nuatigenin
$\mathrm{H}$ Rham-O-Glu-O-Glu
5. 26-Methyl-
nuatigenin
$\mathrm{H} \mathrm{H}$
$\mathrm{Me} \mathrm{H}$
$B: 4$. Isonuatigenin $-\mathrm{H}$

$\begin{array}{lll}\mathrm{R}_{1} & \mathrm{R}_{2}\end{array}$

Thirty five $\mathrm{mg}$ of S-I was hydrolyzed with $5 \mathrm{ml}$ of $1 \mathrm{~N} \mathrm{HCl}$-ethanol $(1: 1 \mathrm{v} / \mathrm{v})$ under reflux for $5 \mathrm{hr}$. The solution was cooled to form the precipitate. The 
precipitate was separated by filtration. The filtrate was neutralized with $\mathrm{Ag}_{2} \mathrm{CO}_{3}$ and sugars in the filtrate were identified by paper chromatography as rhamnose and glucose; Rf (n-butanol-acetic acid $-\mathrm{H}_{2} \mathrm{O}, 4: 1: 5 \mathrm{v} / \mathrm{v}$ upper layer) 0.42 and 0.25 , respectively, and $\mathrm{Rf}$ (n-butanolpyridine $\left.-\mathrm{H}_{2} \mathrm{O}, 6: 4: 3 \mathrm{v} / \mathrm{v}\right) 0$. 61 and 0.41 , respectively. The precipitate was separated by TLC with benzene-acetone $(10: 1 \mathrm{v} / \mathrm{v})$, affording $3(1.1$ $\mathrm{mg}$ ), mp. 163-178 C and 1.5 $\mathrm{mg})$, mp. 178-188 C. Compound 3, $\mathrm{IR} \gamma_{\text {max }}^{\mathrm{KBr}} \mathrm{cm}^{-}: 3450(\mathrm{~s}), 2940$ (s), 1460 (s), 1385 (s), 1190

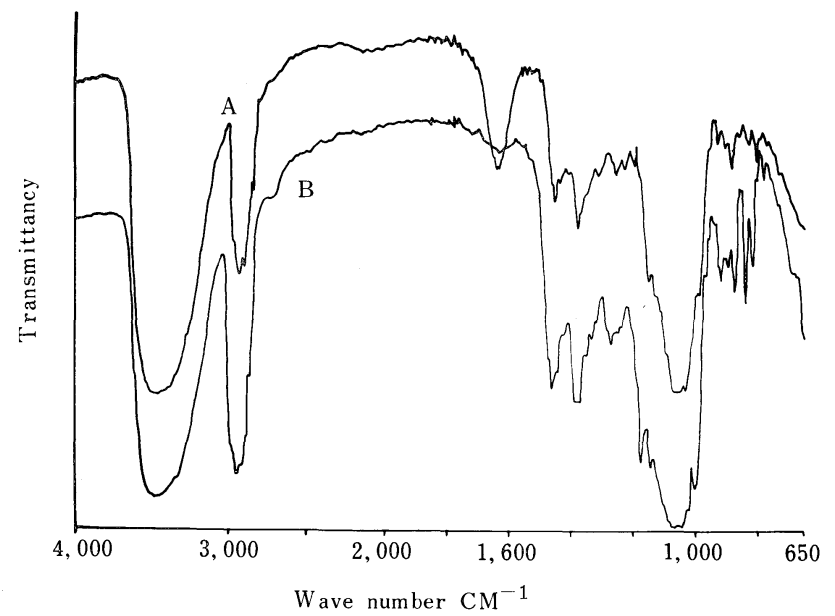

Fig. 2. Infrared spectra of antifungal steroids, S-I and S-II, isolated from oat leaves. A:S-I (26-DGA B). B : S-II (26-DGA A).

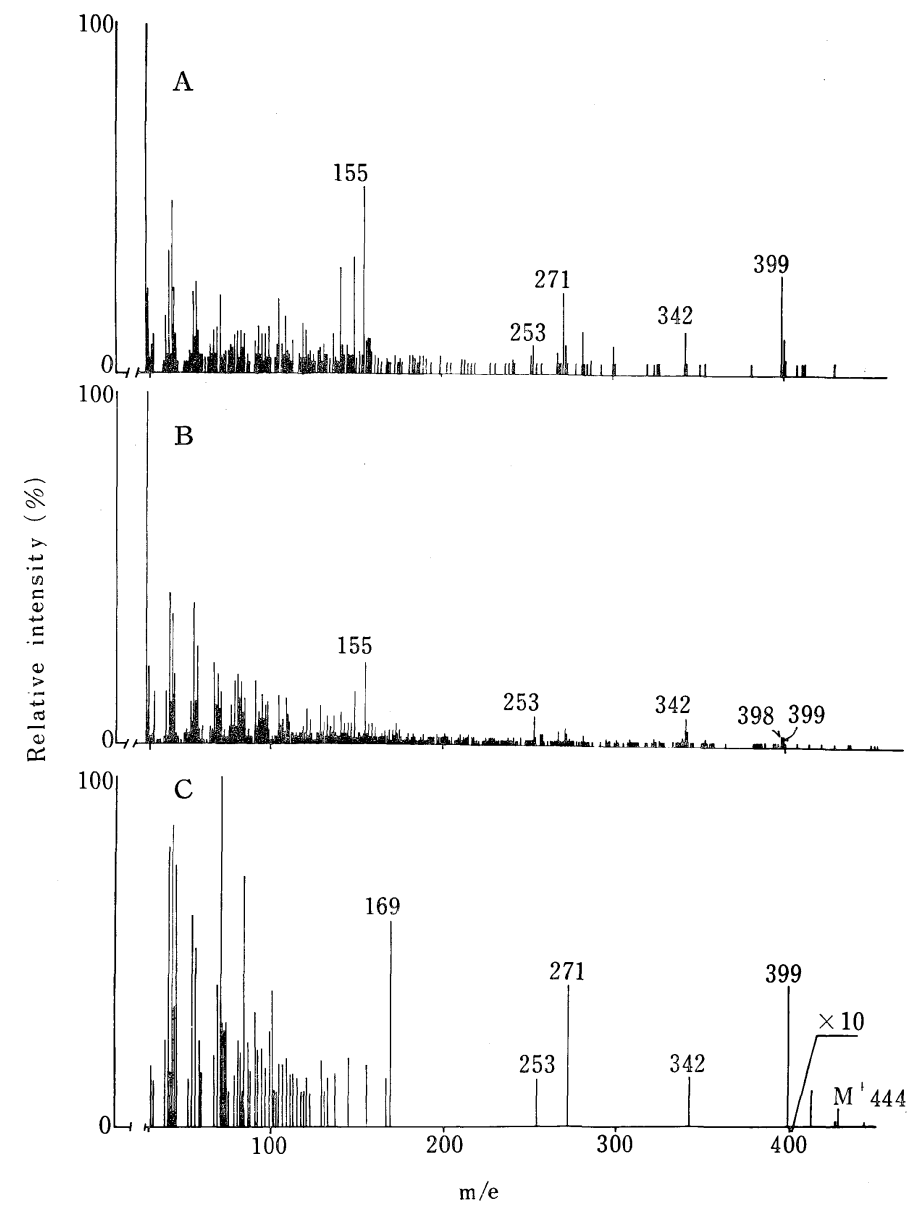

Fig. 3. Mass spectra of aglycon and related compounds from S-I. A : Compound 3 (nuatigenin). B : Compound 4 (isonuatigenin). $\mathrm{C}$ : Compound 5 (26-methylnuatigenin). 
$(\mathrm{m}), 1170(\mathrm{~m}), 1070(\mathrm{~s}), 1030(\mathrm{~s}), 932(\mathrm{~s}), 890(\mathrm{~s})$, was postulated to be nuatigenin ${ }^{11)}$ by MS fragment ions at $\mathrm{m} / \mathrm{e} 399,342,271,253,155$ (Fig. 3-A). Compound 4, $\mathrm{IR} \gamma_{\max }^{\mathrm{KBr}} \mathrm{cm}^{-}: 3450(\mathrm{~s}), 2940(\mathrm{~s}), 1460(\mathrm{~s}), 1385(\mathrm{~s}), 1170(\mathrm{~m}), 1050(\mathrm{~s}), 1012(\mathrm{~s}), 1000(\mathrm{~s})$, $920(\mathrm{~m}), 865(\mathrm{~m})$ exhibited the MS spectrum shown in Fig. $3-\mathrm{B}$. Ion at $\mathrm{m} / \mathrm{e} 398$ and rather weak ion at $\mathrm{m} / \mathrm{e} 399$ suggested that 4 must be isonuatigenin ${ }^{11)}$.

The free hydroxyl group at C-26 position in S-I was clearly shown by the fact that monomethyl ether 5 was given by methylation of S-I, followed by methanolysis. Namely, $2.0 \mathrm{mg}$ of permethylated S-I obtained by Hakomori's method $^{1)}$ was treated with $0.5 \mathrm{ml}$ of $0.7 \mathrm{~N}$ dried $\mathrm{HCl}$ in absolute $\mathrm{MeOH}$ under reflux for $4.25 \mathrm{hr}$. To the solution, $0.5 \mathrm{ml}$ of $2 \mathrm{~N}$ $\mathrm{HCl}$ was added and the solution was refluxed for another $2 \mathrm{hr}$. The reaction mixture was neutralized with $\mathrm{Ag}_{2} \mathrm{CO}_{3}$, filtered and concentrated in vacuo. The residue was separated by silica gel (Merck
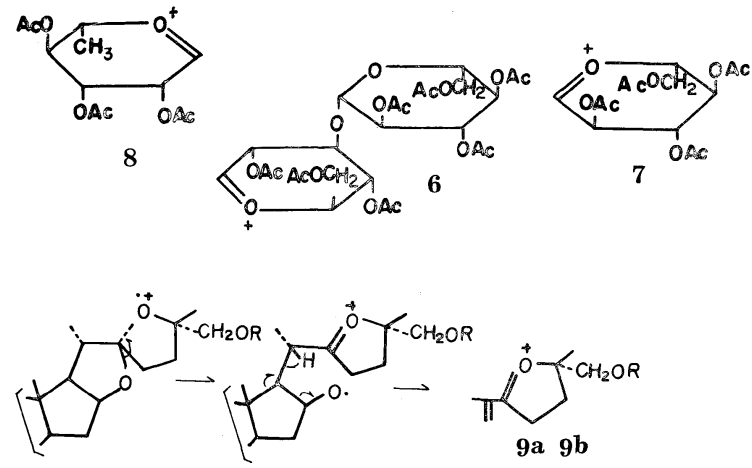

Fig. 4. Mass fragment ions from S-I derivatives. Ions 6,7 and 8 from S-I acetate. 9a $(R=H)$ from nuatigenin (3) and $9 \mathbf{b}(\mathrm{R}=\mathrm{Me})$ from 26-methylnuatigenin (5).

$60 ; 500 \mathrm{mg}$ ) with benzene-ethanol $(10: 1 \mathrm{v} / \mathrm{v})$, giving 5 , 26-methylnuatigenin (below $1 \mathrm{mg})$. The MS spectrum of 5 is shown in Fig. 3-C. The methoxy group in 5 was localized by the shift of MS ion at $\mathrm{m} / \mathrm{e} 155(\mathbf{9 a})$ for 3 to $\mathrm{m} / \mathrm{e} 169$ (9b) for $\mathbf{5}$. From these data, S-I was strongly indicated to be 26-DGA B (1) and the structure was finally confirmed by direct comparison with the authentic sample given by Prof. Schlösser [mixed mp. 298-305 C (no depression), TLC: Rf $\left(\mathrm{CHCl}_{3}-\mathrm{MeOH}-\mathrm{H}_{2} \mathrm{O}, 63\right.$ : $37: 10 \mathrm{v} / \mathrm{v}$ ) 0.45 and IR(superimposable)].

Properties of S-II are as follows. Mp. 298-305 C, $[\alpha]_{\mathrm{D}}-84^{\circ}$ (pyridine, $\mathrm{C}=1.0$ ), analytical value (found: $\mathrm{C}, 59.36 ; \mathrm{H}, 7.38 . \mathrm{C}_{45} \mathrm{H}_{70} \mathrm{O}_{17} \cdot 1.5 \mathrm{H}_{2} \mathrm{O}$ requires, $\mathrm{C}, 59.39 ; \mathrm{H}$, $8.09 \%$ ). IR ( $\mathrm{KBr}$ ) spectrum is shown in Fig. 2-B. Hydrolysis of S-II under the same condition as that for S-I gave rhamnose and glucose as sugars and nuatigenin and isonuatigenin. Thus, S-II was supposed to be 26-DGA A (2) and the structure was also confirmed by direct comparison with the authentic sample from Prof. Tschesche [mixed mp. 300-305 C (no depression), TLC: Rf $\left(\mathrm{CHCl}_{3}-\mathrm{MeOH}-\mathrm{H}_{2} \mathrm{O}, 63\right.$ : $37: 10 \mathrm{v} / \mathrm{v}$ ) 0.55 and IR (superimposable)].

\section{Antifungal activity of leaf constituents}

Frs. W, E, A, S and F obtained from the water homogenate were dissolved in $0.5 \mathrm{ml}$ of deionized water and inhibitory activity of each solution was examined for uredospore germination of $P$. coronata avenae race 226 . Majority of the activity was found in Frs. M, A and S. Fr. F exhibited relatively low activity, compared with Fr. S, and Frs. $W$ and $E$ had no activity. No other active substance than S-I (26-DGA B), S-II (26-DGA A), RIS and UF could be detected on the TLC plates. The effect of each fraction obtained from the hot $\mathrm{MeOH}$ extract was also examined by the same manner. Results indicated that the major inhibitors were present in Fr. F. No antifungal substance other than RIS and UF was found on the TLC plates.

26-DGA A and B isolated from Fr. S of the water homogenate inhibited the germ tube growth of $P$. coronata avenae giving the $\mathrm{ED}_{80}$ value of $14 \mu \mathrm{g} / \mathrm{ml}$ for 
both substances. The inhibitory activity of the two flavonoids was relatively low so that the $\mathrm{ED}_{80}$ value could not be estimated; the $\mathrm{ED}_{50}$ value was 1,500 and 500 $\mu \mathrm{g} / \mathrm{ml}$ for RIS and UF, respectively.

Table 1. Effect of 26-DGA A and B and RIS on germ tube growth of uredopsores

\begin{tabular}{|c|c|c|c|c|c|c|c|}
\hline \multirow{3}{*}{ Fungus } & \multirow{3}{*}{$\begin{array}{c}\text { Germ tube length } \\
\text { on water } \\
\text { (as control) } \\
(\mu \mathrm{m})\end{array}$} & \multicolumn{6}{|c|}{ Growth ratio ( $\%$ of control) } \\
\hline & & \multicolumn{3}{|c|}{ 26-DGA A } & \multicolumn{2}{|c|}{ 26-DGA B } & \multirow{2}{*}{$\frac{\text { RIS }}{2,000}$} \\
\hline & & $7 \mu \mathrm{g}$ & 10 & 14 & 10 & 14 & \\
\hline \multicolumn{8}{|l|}{ P. coronata avenae } \\
\hline race 226 & 755 & 92 & 57 & 17 & 91 & 20 & 51 \\
\hline race 203 & 844 & 103 & 31 & 11 & 95 & 17 & 39 \\
\hline P. coronata lolii & 743 & 79 & 76 & 32 & 71 & 17 & 34 \\
\hline P. coronata festucae & 820 & 92 & 34 & 10 & 67 & 16 & 39 \\
\hline P. graminis tritici & 933 & 83 & 56 & 22 & 59 & 15 & 54 \\
\hline P. graminis dactylidis & 677 & 82 & 18 & 16 & 68 & 18 & 71 \\
\hline
\end{tabular}

Average of two replications; length of 100 germ tubes was mesured in each experiment.

Inhibitory activity of these four substances was also estimated for various rust fungi (Table 1). There was no distinguishable difference between the pathogen and non-pathogens in sensitivity to these inhibitors. No change in germination percent was found at any concentration tested.

\section{Content of inhibitors in leaves}

The TLC profiles of Frs. $S$ and $F$ prepared from the water homogenate of leaves are shown in Fig. 5-A and -C. The amounts of 26-DGA A and B, RIS and UF were calculated to be $280,930,750$ and $300 \mu \mathrm{g} / \mathrm{g}$ fr. wt, respectively. However, when Fr. S was prepared from intact leaves by extracting with hot $\mathrm{MeOH}$, neither 26-DGA A nor $\mathrm{B}$ was detected on the TLC (Fig. 5-B), indicating that 26-DGAs were absent in intact leaves, while the contents of RIS and UF were identical to those in Fig. 5-C (Fig. 5-D). Two peaks in Fig. 5-B were presumed to be avenacosides, precursors of $26-\mathrm{DGAs}^{4,5,12)}$.

\section{Discussion}

The presence of two antifungal steroids named as 26-desglucoavenacosides (26DGA) A and B in leaves of oat was reported in 1976 by Lüning and Schlösser ${ }^{4)}$ and their chemical structures were elucidated by Tschesche and Wiemann in 197712). We independently isolated two antifungal steroids from Shokan 1 oat leaves and identified as the same compounds. However, the contents of 26-DGA A and B determined in the present study were about one third that reported by Lüning and Schlösser ${ }^{4)}$. Two flavonoids, RIS and UF, were newly isolated as growth inhibitors of rust fungi. No other antifungal substance than these four compounds could be isolated in this study.

The proposal by Lüning and Schlösser ${ }^{3)}$ that intact leaves contained no 26-DGAs was also confirmed in this study (Fig. 5-A and -B). Our present results add fruther information that the two flavonoids RIS and UF are the major antifungal 


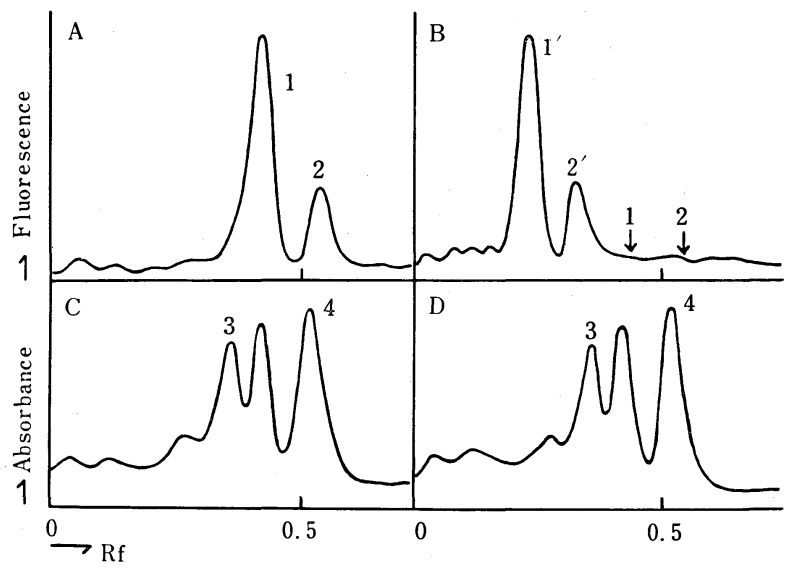

Fig. 5. TLC profiles of steroid-rich (Fr. S) and flavonoid-rich (Fr. F) fractions isolated from Shokan 1 oat leaves. A and C: Fractions from water homogenate of leaves. B and D: Fractions from hot $\mathrm{MeOH}$ extract. A and B:Fr. S. C and D:Fr. F. 1:26-DGA B. 2:26-DGA A. 3:UF. 4:RIS. Two peaks, $1^{\prime}$ and $2^{\prime}$ in $B$ seem to be avenacosides $B$ and $A$, respectively, which are the precursors of 26-DGAs.

substances in intact leaves, and that antifungal activity in injured leaves is attributable to 26-DGAs rather than the flavonoids. It is doubted, however, that 26-DGAs are responsible as preformed substances to the species-species specificity in the oat-rust combinations, because the difference in sensitivity between the pathogenic and non-pathogenic rust fungi is hardly detectable for these inhibitors (Table 1).

We thank Prof. S. Sakamura (Univ. of Hokkaido) for advice, Prof. E. Schlösser (Univ. of Giessen) and Prof. R. Tschesche (Univ. of Bonn) for suggestions and supply of authentic 26-DGAs. We also thank Mr. N. Nomura (JEOL Ltd.) for the mass spectrum.

\section{Literature cited}

1. Hakomori, S. (1964). J. Biochem. 55 : 205-207.

2. Ingham, J. L. (1973). Phytopath. Z. 78: 314-335.

3. Lüning, H. U. and Schlösser, E. (1975). Z. PflKrankh. PflSchutz. 82: 699-703.

4. Lüning, H. U. and Schlösser, E. (1976). Angew. Botanik. 50:49-60.

5. Lüning, H. U. and Schlösser, E. (1976). Z. PflKrankh. PflSchutz. 83: 317-327.

6. Mahadevan, A. (1970). Phytopath. Z. 68:73-80.

7. Nabeta, K., Kadota, G. and Tani, T. (1977). Phytochemistry 16:1112-1113.

8. Schönbeck, F. (1976). Specificity in Plant Diseases (Wood, R. K. S. and Graniti, A. eds.) Plenum Press, New York. pp. 237-252.

9. Schönbeck, F. and Schlösser, E. (1976). Physiological Plant Pathology (Heitefuss, R. and Williams, P. H. eds.) Springer-Verlag, Berlin. pp. 653-678.

10. Tani, T., Yamamoto, H., Onoe, T. and Naito, N. (1975). Physiol. Plant Path. $7: 231-242$. 
11. Tschesche, R. and Richert, K. H. (1964). Tetrahedron Lett. $20: 387-398$.

12. Tschesche, R. and Wiemann, W. (1977). Chem. Ber. 110:2416-2423.

13. Yamashita, K. (1975). Biologically Active Substances Produced by Plants (in Japanese). Nankodo Co., Tokyo. pp. 185.

\section{和 文 摘 要}

健全エンバク葉に存在するさび菌発育阻害物質

$$
\text { 鍋田憲助・門田源一・谷 利一・志賀宏志 }
$$

エンバク初生葉の水磨砕物から 2 種の抗菌性ステロイドを分離し，26-desglucoavenacosid (26-DGA) A 抢よび B と同定した。また，2種の抗菌性フラボノイド O”-rhamnosylisoswertisin (RIS) および未同 定物質（UF）を分離した。Puccinia coronata avenae 夏胞子の発芽管伸長阻害力は RIS および UF（そ れぞれ $\mathrm{ED}_{50}=1,500$ および $\left.500 \mu \mathrm{g} / \mathrm{ml}\right)$ にくらべて26-DGA A, B $\left(\mathrm{ED}_{80}=14 \mu \mathrm{g} / \mathrm{ml}\right)$ が極めて大きかっ た。生重 $1 \mathrm{~g}$ あたりの 26-DGA A,B の含量は水磨砕物からはそれぞれ $930,280 \mu \mathrm{g}$ と算出されたが, 生葉を 熱メタノールに浸漬後に磨砕した場合には両物質とも痕跡しか検出されなかった。一方，RISおよびUFの

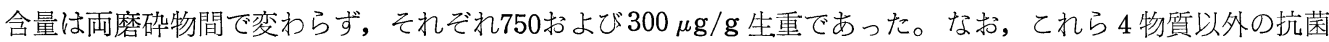
性物質は検出されなかった。以上の結果から，水磨砕物の抗菌性は主として26-DGA A,Bによるが，それ らは磨砕による傷害のために生成されたものであり，intact な生葉では RIS と UF が抗菌性の主成分である と考える。ただし，乙れらの抗菌物質はエンバクーさび菌の組み合せにおける種間特異性には関与しないと 推定した。 